\title{
The Response of U.S. States to Exogenous Oil Supply and Monetary Policy Shocks
}

\author{
Bebonchu Atems ${ }^{1, *}$ \& Eddery Lam ${ }^{2}$ \\ ${ }^{1}$ School of Business, Clarkson University, Potsdam, New York 13699, USA \\ ${ }^{2}$ Department of Economics, University of Nebraska at Kearney, Kearney, Nebraska 68849, \\ USA \\ *Corresponding author: School of Business, Clarkson University, 8 Clarkson Avenue, \\ Potsdam, New York 13699, USA. Tel: 1-315-268-4469Ｅ-mail: batems@clarkson.edu
}

Received: June 28, 2013

doi:10.5296/rae.v5i3.3937
Accepted: August 1, 2013 Published: August 27, 2013

URL: http://dx.doi.org/10.5296/rae.v5i3.3937

\begin{abstract}
We make use of new methodological advances in quantifying oil supply and monetary policy shocks that are exogenous with respect to macroeconomic conditions to examine the response of state economies to these shocks. Our approach is parsimonious and straightforward: once exogenous oil supply shocks and monetary policy shocks have been identified, the dynamic response of state economies to exogenous shocks can be analyzed directly using ordinary least squares (OLS) and other conventional methods of inference. The fact that no identifying assumptions are required makes our findings invariant to different identification schemes. Results indicate that an exogenous monetary policy shock typically causes a decrease in real personal income. The paper also documents a fair degree of similarity in the response of real personal income to exogenous oil supply across many states. Like the aggregate response, following an exogenous oil supply shock, real personal income decreases in many states.
\end{abstract}

Keywords: exogenous oil supply shocks; monetary shocks; impulse response functions JEL Codes: E32, E52, R11 


\section{Introduction}

A large body of research exists on the effects of oil price shocks and monetary policy shocks on the economy. Much of that research examines the effects of these shocks on the national economies of the United States and other OECD countries.(Note 1) Regional economies, however, do not respond identically following macroeconomic shocks. Several factors, including differences in regional labor market structures, regional differences in the mix of interest-sensitive industries, regional differences in the size of industries, regional differences in the availability of credit (Carlino and DeFina, 1998), as well differences in business amenities across regions potentially explain the mechanism by which oil and monetary shocks affect regional economies.

Until recently, the experience of these shocks at the sub-national level has received considerably less attention, notwithstanding notable studies by Carlino and DeFina (1998, 1999a), Owyang and Wall (2009), and Beckworth (2010) for the regional effects of monetary policy; and Yamashiro and Grobar (2005), Engemann, Owyang and Wall (2011) for the effects of oil price shocks. This study focuses on the U.S. state-level responses to exogenous oil supply and monetary policy shocks. Some researchers may object to the choice of states for the analysis because states are strictly political designations. The use of state-level data, rather than data on other areal units which may be functional economic areas, however, has several advantages. Firstly, state-level real personal income is available at the quarterly frequency, whereas such data set for other areas, say the 177 Bureau of Economic Analysis regions is difficult to find at the quarterly frequency. Secondly, the use of state-level data can be justified by state-level policy interventions, whereas other areal units, which sometimes may include multiple states, makes policy interventions difficult. In addition, Engemann, Owyang and Wall (2011) note that an advantage of state-level data over aggregate U.S. data is that given the size of the U.S. economy, the typical assumption that oil price shocks are exogenous to the aggregate U.S. economy is questionable, but this assumption is more credulous using state-level data. Carlino and DeFina (1999b) further note that state-level data is important because:

"First, states within a region may have quite varied responses to monetary policy actions: responses different from one another and from the region's overall response... Second, a state-level study provides 48 individual responses to monetary policy actions, not just the eight responses in our regional study The states, therefore, provide a richer testing ground for determining the sources of the differential responses.” (pages 17 - 18)

Our study differs from previous studies in several ways. Firstly, we make use of new methodological advances in quantifying oil supply (as in e.g. Kilian, 2008b) and monetary policy shocks (as in e.g. Romer and Romer, 2004) that are exogenous with respect to macroeconomic conditions, to examine the response of state economies to these shocks. A well-known challenge in assessing how the economy responds in the wake of oil supply and monetary policy shocks is providing valid assumptions to identify exogenous movements in oil prices or the monetary policy instrument. Such an exercise is not well defined because of the endogeneity of monetary policy and oil prices to important macroeconomic data (Romer 
and Romer, 2004). Consider, for example the "price puzzle”, whereby a negative monetary policy shock causes prices to rise, or stay flat, for a significant period following the shock (e.g. Hanson, 2004). Cover (2008) argues that a possible reason for this puzzle is that the monetary policy shock series derived from these models are not really exogenous. Christiano, Eichenbaum and Evans (1999), among others, note that such a response to a monetary contraction may be indicative of the endogeneity, rather than exogeneity of monetary policy. To tackle this issue, Romer and Romer (2004) derive a series of monetary policy shocks that is "relatively free of both endogenous and anticipatory actions" (page 1056). Coibion et al. (2012) extend the Romer and Romer (2004) series of exogenous monetary policy to 2008:12. We use this measure of exogenous monetary policy shocks as the monetary policy variable.

Kilian (2008b) points out that treating innovations to oil prices as exogenous supply shocks is problematic because the response of the economy will differ depending on the underlying source of the oil price movement. The response of the economy will depend on whether the oil price spike is the result of oil demand shocks, or exogenous oil supply shocks. Kilian (2008b) summarizes his argument as follows:

"In particular, there is reason to believe that oil price innovations in vector autoregressive models may also reflect shifts in the demand for crude oil as suggested by sharp increases in industrial commodity prices during times of major global economic expansions.” (page 5)

Kilian (2008a) thus proposes a methodology for quantifying the shortfall of OPEC oil production caused by exogenous political events, and uses the new methodology to construct a series of exogenous oil supply shocks. Following Kilian's (2008a) narrative approach, we extend his series of exogenous oil supply shocks to 2008:Q4 and use this series of shocks as our oil supply shock measure.

Secondly, previous studies on the effects of macroeconomic shocks on state economies have typically employed a vector autoregressive (VAR) framework. In order to generate impulse responses using VAR models, certain identifying assumptions must be made. The results from these studies therefore crucially depend on the assumptions made. In this paper, we apply the recent approach by, among others, Kilian (2008b), and Romer and Romer (2004), which avoids the conceptual and econometric difficulties employed by previous studies to state-level economies. The approach is parsimonious and straightforward: once exogenous oil supply shocks and monetary policy shocks have been identified, the dynamic responses of state economies to exogenous shocks can be analyzed directly using ordinary least squares (OLS) and other conventional methods of inference (Kilian, 2008a,b). The fact that no identifying assumptions are required makes our findings invariant to different identification schemes (Kilian 2008b).

Our econometric results suggest that following a one percentage point realization in the monetary policy shock, real state-level personal incomes typically tend to decline in many states. Quantitatively, there is considerable heterogeneity across states' real personal income responses to monetary shocks, evident in the magnitude and persistence of the effects of the shocks. The response of real personal income to our oil supply shock shows a pattern 
whereby after an initial overshooting, real state personal income decreases in many states.

The rest paper proceeds as follows. In section 2, we hypothesize and discuss potential reasons why states should respond differently to exogenous shocks. Section 3 describes the data used, and the methodology employed in estimating the impacts of exogenous oil supply and monetary policy shocks. Section 4 presents the impulse responses and discusses why states respond to the exogenous shocks in the way they do. Section 5 concludes.

\section{Why Should States Respond Differently to Monetary Policy and Oil Supply Shocks?}

The literature on the effects of oil and monetary policy shocks suggest reasons why these shocks might affect different states differently. Carlino and DeFina (1999a) point out that state differences in the mix of industries, the number of large versus small firms, and the number of large versus small banks in a state all determine the state's response to monetary shocks. In addition to these factors, oil production by state, the share of total state employment accounted for by oil, and the percent of gross state product accounted for by oil are among several reasons why oil shocks potentially have differential effects across states.

Monetary policy primarily affects the economy through its effect on the short term interest rate. Through its direct control of short term interest rates, the Federal Reserve indirectly influences long term rates, which then affect interest-sensitive sectors of the economy such as manufacturing, construction, transportation, and finance, insurance and real estate (FIRE). For example, a monetary tightening by the Federal Reserve that raises interest rates makes it more expensive for individuals to borrow for the purchase of high-value items such as houses, cars, appliances and furniture, thereby decreasing the demand for these (and related) products. Furthermore, a monetary tightening also makes it difficult for manufacturers, and other businesses to borrow to invest in equipment, inventories, and buildings, thereby hurting the manufacturing, construction, and FIRE industries, and consequently the entire economy. Thus the impact of monetary policy on a state depends on the mix of interest-sensitive industries within the state.

Table 1 shows the percent of total state income accounted for by selected interest-sensitive industries across states. Table 1a shows manufacturing output as a percent of total state output, and Table 1b shows manufacturing income as a percent of gross state income (average over the 1970-2010 period). These tables show wide variations in industry mix across states, with manufacturing accounting for over 29 percent of gross state product and 21.9 percent of total state income in Indiana, while the share of gross state income accounted for by manufacturing is only 3.21 percent in Wyoming. Therefore, ceteris paribus one should expect Indiana (and other states with high manufacturing shares of total income) to be more responsive to monetary shocks than Wyoming (and other states with lower manufacturing income shares of total income). Table 1 also shows the share of total income accounted for by construction, transportation, and finance, insurance and real estate (FIRE). In general, the table shows less variation in industry mix for the construction, transportation, and FIRE industries across states, suggesting that among the industries in Table 1, the impact of 
monetary policy on state income is probably primarily driven by the interest-sensitivity of the manufacturing industry.

Table 1: Percent of Total Income Accounted for by Selected Interest-Sensitive Industries

(a) Percent of Total State Output Accounted for by Manufacturing Output

\begin{tabular}{llllll}
\hline State & Percent & State & Percent & State & Percent \\
\hline Indiana (IN) & 29.08 & New Hampshire (NH) & 17.73 & New Jersey (NJ) & 13.47 \\
North Carolina (NC) & 24.49 & Minnesota (MN) & 16.51 & California (CA) & 12.96 \\
Wisconsin (WI) & 24.33 & Illinois (IL) & 16.44 & Utah (UT) & 12.73 \\
Michigan (MI) & 24.32 & Vermont (VT) & 16.41 & Nebraska (NE) & 12.7 \\
Ohio (OH) & 23.95 & Kansas (KS) & 16.01 & Virginia (VA) & 12.5 \\
Kentucky (KY) & 22.77 & Connecticut (CT) & 15.99 & Arizona (AZ) & 10.97 \\
South Carolina (SC) & 21.68 & Georgia (GA) & 15.27 & South Dakota (SD) & 10.31 \\
Iowa (IA) & 21.61 & Maine (ME) & 15.19 & New York (NY) & 10.19 \\
Oregon (OR) & 20.64 & Idaho (ID) & 14.84 & New Mexico (NM) & 9.87 \\
Arkansas (AR) & 20.55 & West Virginia (WV) & 14.61 & Colorado (CO) & 9.13 \\
Tennessee (TN) & 20.12 & Rhode Island (RI) & 14.61 & Maryland (MD) & 8.08 \\
Mississippi (MS) & 19.68 & Massachusetts (MA) & 14.48 & North Dakota (ND) & 7.45 \\
Alabama (AL) & 19.52 & Texas (TX) & 14.26 & Montana (MT) & 6.99 \\
Pennsylvania (PA) & 18.43 & Washington (WA) & 14.24 & Florida (FL) & 6.83 \\
Missouri (MO) & 17.76 & Delaware (DE) & 14.21 & Wyoming (WY) & 5.13 \\
Louisiana (LA) & 17.76 & Oklahoma (OK) & 13.56 & Nevada (NV) & 4.15 \\
\hline
\end{tabular}

(b) Manufacturing Share of Total Income

(c) Finance, Insurance, and Real Estate Income

\begin{tabular}{llllllllllll}
\hline State & Percent & State & Percent & State & Percent & State & Percent & State & Percent & State & Percent \\
\hline IN & 21.90 & IL & 13.68 & WV & 10.44 & NY & 14.17 & NV & 5.59 & MI & 4.29 \\
MI & 21.83 & MS & 13.67 & OK & 10.35 & DE & 10.56 & MO & 5.52 & SC & 4.28 \\
WI & 19.05 & VT & 13.60 & NE & 9.63 & CT & 10.34 & RI & 5.50 & IN & 4.22 \\
OH & 18.98 & MO & 13.19 & LA & 9.40 & MA & 8.36 & PA & 5.46 & ND & 4.19 \\
DE & 16.47 & KS & 13.03 & NY & 8.85 & IL & 7.60 & TN & 5.24 & AL & 4.04 \\
NC & 15.94 & OR & 12.99 & AZ & 8.51 & CO & 6.86 & NH & 5.19 & MT & 4.04 \\
SC & 15.85 & RI & 12.62 & VA & 8.20 & MN & 6.71 & MD & 5.12 & LA & 4.01 \\
TN & 15.28 & MA & 12.59 & CO & 7.93 & AZ & 6.51 & NC & 5.09 & VT & 3.97 \\
IA & 14.86 & ME & 12.11 & SD & 7.65 & NJ & 6.47 & SD & 5.02 & OK & 3.96 \\
KY & 14.56 & WA & 11.46 & MD & 5.90 & CA & 6.36 & VA & 5.00 & KY & 3.86 \\
CT & 14.44 & GA & 11.35 & ND & 5.25 & TX & 6.18 & WI & 4.96 & ID & 3.83 \\
AL & 14.43 & CA & 10.99 & FL & 5.11 & GA & 5.94 & WA & 4.90 & AR & 3.57 \\
MN & 14.37 & NJ & 10.98 & MT & 4.77 & FL & 5.87 & OH & 4.86 & NM & 3.52 \\
PA & 14.30 & ID & 10.73 & NM & 4.52 & NE & 5.78 & OR & 4.79 & WY & 3.38 \\
AR & 14.27 & TX & 10.55 & NV & 3.32 & UT & 5.75 & KS & 4.61 & MS & 3.26 \\
NH & 13.93 & UT & 10.47 & WY & 3.21 & IA & 5.64 & ME & 4.47 & WV & 2.69 \\
\hline
\end{tabular}


(d) Construction Income Share of Total Income

(e) Transportation Income Share of Total Income

\begin{tabular}{llllllllllll}
\hline State & Percent & State & Percent & State & Percent & State & Percent & State & Percent & State & Percent \\
\hline NV & 8.17 & MD & 5.16 & PA & 4.53 & NE & 6.60 & OK & 4.48 & VA & 3.61 \\
WY & 6.76 & ME & 5.15 & IL & 4.50 & WY & 5.60 & NJ & 4.48 & NY & 3.60 \\
UT & 6.27 & MO & 5.03 & KY & 4.49 & GA & 5.56 & IN & 4.18 & NM & 3.60 \\
ID & 6.19 & NC & 5.02 & SD & 4.45 & TX & 5.16 & PA & 4.11 & CA & 3.55 \\
CO & 6.18 & OR & 5.00 & WV & 4.41 & MO & 5.16 & MN & 4.10 & SC & 3.36 \\
AZ & 5.98 & TN & 4.96 & KS & 4.38 & LA & 5.10 & IA & 3.96 & AZ & 3.28 \\
LA & 5.92 & VA & 4.89 & MS & 4.33 & ND & 5.08 & OR & 3.94 & MI & 3.27 \\
TX & 5.76 & IN & 4.87 & MA & 4.32 & AR & 5.06 & OH & 3.87 & FL & 3.25 \\
DE & 5.63 & GA & 4.76 & AR & 4.30 & TN & 5.02 & AL & 3.83 & DE & 3.11 \\
VT & 5.59 & MN & 4.75 & OH & 4.24 & KY & 4.90 & WA & 3.80 & ME & 3.11 \\
MT & 5.54 & CA & 4.72 & CT & 4.22 & UT & 4.87 & MS & 3.78 & VT & 3.01 \\
NH & 5.48 & AL & 4.71 & MI & 4.06 & MT & 4.84 & NV & 3.72 & MA & 2.94 \\
WA & 5.37 & NE & 4.68 & OK & 3.98 & KS & 4.80 & WI & 3.71 & MD & 2.92 \\
ND & 5.36 & WI & 4.67 & RI & 3.88 & CO & 4.77 & ID & 3.68 & CT & 2.72 \\
SC & 5.20 & FL & 4.63 & NJ & 3.87 & IL & 4.62 & SD & 3.67 & RI & 2.40 \\
NM & 5.17 & IA & 4.58 & NY & 3.32 & WV & 4.56 & NC & 3.62 & NH & 2.38 \\
\hline
\end{tabular}

Notes: Data source: United States Bureau of Economic Analysis (BEA)

Several papers have identified other channels through which monetary policy potentially affects states. Carlino and DeFina (1999a) identify possible credit channels, where monetary policy affects state economies through their effect on banks' ability to provide loans. A monetary contraction decreases bank reserves and deposits, thereby decreasing the quantity of loans banks can provide. This decrease in loans decreases incomes. An implication of this so-called credit channel is that monetary policy has a more significant effect on small firms that heavily rely on bank loans than larger firms that rely relatively less on banks since larger firms have direct access to credit markets through stock and bond markets (Mishkin, 1996). Therefore monetary policy should have a more significant effect on states with a large share of small firms than states with a large share of larger firms, ceteris paribus. Carlino and DeFina (1999a) show that the percentage of small and large firms varies considerably across U.S. states, with small firms accounting for 89.1 percent of total state employment in Montana, but only 48.8 percent in Connecticut. They also show that the share of total loans made by a state's small banks also varies widely across states, with a high of 73 percent in North Dakota, and a low of 0.9 percent in New York. Therefore, according to the credit channel, one would expect North Dakota to be more responsive to a monetary policy shock than New York.

Just as monetary policy is expected to have differential state effects, oil shocks should affect states differently as well. In fact, some of the factors that explain why monetary policy has differential state effects, such as differences in industry mix, also potentially explain why oil supply shocks should have differential regional effects. For example, Lee and Ni (2002) find 


\section{Macrothink Institute ${ }^{\mathrm{TM}}$}

that oil shocks decrease output in industries that have a large cost share of oil, such as petroleum refinery and industrial chemicals which accounted for over 55 percent of energy used by all manufacturing industries in 1994; while for other industries such as the the automobile industry, oil shocks decrease their demand. Therefore for states that have industries with a large cost share of oil, positive oil shocks are expected to decrease gross state product, and states with industries such as the automobile industry, oil supply shocks decrease demand and incomes.

In addition, it is expected that states that produce large quantities of oil, or states for which a large share of gross state product or income is accounted for by oil tend to be more responsive to oil shocks. Table 2a shows the average crude oil production (thousand barrels) by state; Table $2 \mathrm{~b}$ shows the percent of gross state output accounted for by oil and gas production; Table 2c, the percent of gross state income accounted for by oil and gas; and Table 2d, the percent of state employment accounted for employment in oil and natural gas. Based on these tables, the economies of states like Wyoming, Oklahoma, Louisiana and Texas which rely relatively more on oil, are expected to be more responsive to oil shocks than state economies that are relatively less dependent on oil, such as Nevada, Minnesota, and Missouri.

Table 2: Oil Production and the U.S. States

(a) Average Crude Oil Production(thousand barrels) by state: $1981-2010$

\begin{tabular}{|c|c|c|c|c|c|c|c|c|c|c|c|}
\hline State & Output & State & Output & State & Output & State & Percent & State & Percent & State & Percent \\
\hline TX & 49312.98 & UT & 1953.87 & IN & 241.72 & WY & 17.71 & UT & 1.12 & IL & 0.08 \\
\hline CA & 24080.09 & MT & 1947.01 & PA & 229.99 & LA & 13.52 & WV & 1.02 & FL & 0.07 \\
\hline LA & 10505.97 & IL & 1396.68 & WV & 179.46 & $\mathrm{OK}$ & 7.99 & $\mathrm{AR}$ & 0.80 & SD & 0.07 \\
\hline OK & 8169.02 & MI & 1213.46 & SD & 119.22 & $\mathrm{TX}$ & 7.76 & CA & 0.68 & VA & 0.06 \\
\hline WY & 6800.89 & $\mathrm{AL}$ & 1193.26 & $\mathrm{NV}$ & 118.88 & $\mathrm{NM}$ & 7.62 & $\mathrm{AL}$ & 0.66 & $\mathrm{NV}$ & 0.04 \\
\hline NM & 5697.48 & $\mathrm{AR}$ & 849.17 & $\mathrm{TN}$ & 39.60 & ND & 3.35 & MI & 0.22 & $\mathrm{TN}$ & 0.03 \\
\hline ND & 4101.49 & $\mathrm{OH}$ & 712.12 & NY & 36.05 & MT & 2.04 & $\mathrm{OH}$ & 0.21 & NY & 0.02 \\
\hline KS & 3996.36 & FL & 603.65 & MO & 11.08 & $\mathrm{CO}$ & 1.85 & KY & 0.18 & IN & 0.02 \\
\hline $\mathrm{CO}$ & 2293.91 & KY & 354.97 & $\mathrm{AZ}$ & 8.82 & KS & 1.56 & PA & 0.14 & ID & 0.01 \\
\hline MS & 2001.74 & $\mathrm{NE}$ & 352.45 & VA & 1.52 & MS & 1.39 & $\mathrm{NE}$ & 0.08 & MN & 0.01 \\
\hline
\end{tabular}

(b) Percent of Gross State Product Accounted for by Oil and Gas Production: 1970-2010 
(c) Percent of Gross State Income Accounted for

(d) Percent of State Employment Accounted for by

by Oil and Natural Gas Income: 1970-2910

Employment in Oil and Natural Gas: 1970-2010

\begin{tabular}{llllllllllll}
\hline State & Percent & State & Percent & State & Percent & State & Percent & State & Percent & State & Percent \\
\hline WY & 4.87 & MS & 0.61 & NY & 0.10 & WY & 3.14 & MT & 0.46 & SD & 0.07 \\
OK & 4.43 & UT & 0.34 & DE & 0.07 & OK & 3.02 & AR & 0.32 & AL & 0.07 \\
TX & 3.72 & AR & 0.33 & NE & 0.07 & LA & 2.15 & UT & 0.22 & IN & 0.06 \\
LA & 3.00 & CA & 0.25 & VA & 0.06 & TX & 1.77 & KY & 0.19 & ID & 0.06 \\
NM & 1.48 & KY & 0.21 & MA & 0.06 & KS & 1.12 & CA & 0.16 & MD & 0.05 \\
CO & 1.31 & OH & 0.19 & SD & 0.06 & NM & 1.07 & OH & 0.16 & NY & 0.05 \\
KS & 0.89 & IL & 0.18 & MA & 0.06 & CO & 0.64 & IL & 0.14 & NV & 0.05 \\
ND & 0.80 & PA & 0.15 & IN & 0.06 & ND & 0.58 & NE & 0.09 & AZ & 0.04 \\
WV & 0.72 & AL & 0.13 & FL & 0.05 & WV & 0.50 & PA & 0.09 & TN & 0.04 \\
MT & 0.64 & MI & 0.13 & NV & 0.06 & MS & 0.49 & MI & 0.09 & MO & 0.04 \\
\hline
\end{tabular}

Notes: Data source: United States Bureau of Economic Analysis (BEA)

\section{Data and Methodology}

\subsection{Data}

Following Romer and Romer (2004), Coibion et al. (2012) construct a monthly series of exogenous monetary policy shocks from 1969:1 to 2008:12. We aggregate their monthly series to its quarterly frequency, and use as the measure of exogenous monetary policy shocks. Following Kilian's (2008b) narrative approach for quantifying OPEC oil production shortfalls caused by external political events, we construct a series of exogenous oil supply shocks. The top panel of Figure 1 presents a graph of the monetary policy shock and the bottom panel shows the graph of the oil supply shock. State-level personal incomes (deflated using core CPI) were downloaded from the Federal Reserve Economic Data of the Federal Reserve Bank of St. Louis. All the data used in the paper are quarterly from 1971:Q1 to 2008:Q4.

Following the convention in the literature, we pretest state-level real personal incomes for stationarity carrying out an augmented Dickey-Fuller (ADF) test. The results of this test are shown in Table 3 . Compared to the $5 \%$ critical value of -3.343 , the conclusion from this test is that for all states, real personal income is nonstationary in levels but stationary in first differences. Therefore, the estimated model includes the stationary log-differenced state-level real personal income and the identified exogenous monetary policy and oil supply shocks.

\subsection{Methodology}

To examine the effects of monetary policy shocks on national and state economies, previous studies have typically employed a structural vector autoregressive (VAR) approach.(Note 2) Traditional VAR models, however, usually require making several identifying assumptions. At the state-level, traditional VAR models are equally problematic because a consistent measure of oil price and monetary policy shocks is needed in order to compare the effects of 
monetary policy and oil supply shocks across states (Beckworth 2010). Estimating such a measure requires the inclusion of all states in the VAR. Depending on the number of states, estimating a traditional VAR could result in serious degrees of freedom problems, because such an estimation requires the estimation of a large number of parameters, relative to sample size (Yamashiro and Grobar, 2005). Given the small time series usually available at the state level, such an estimation procedure may result in a reduction in efficiency.

(a) Measure of Exogenous Monetary Policy Shocks: 1971.I - 2008.IV

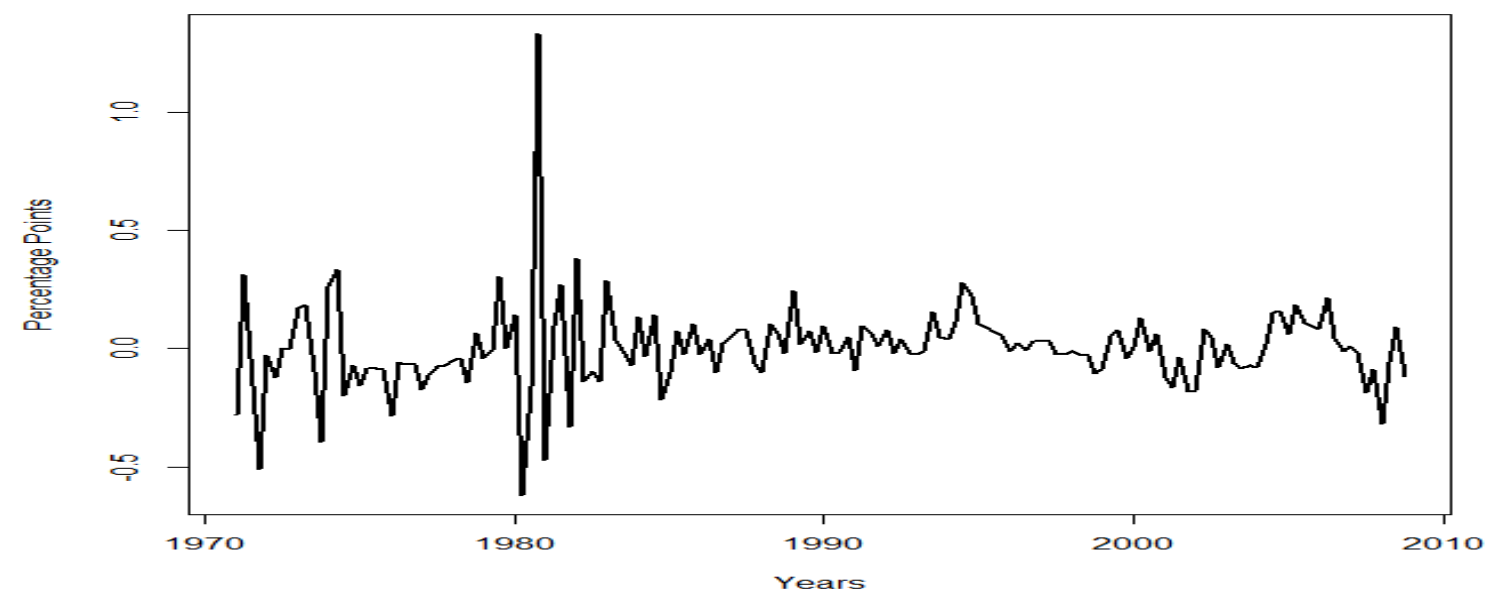

(b) Measure of Exogenous Oil Supply Shocks: 1971.I - 2008.IV

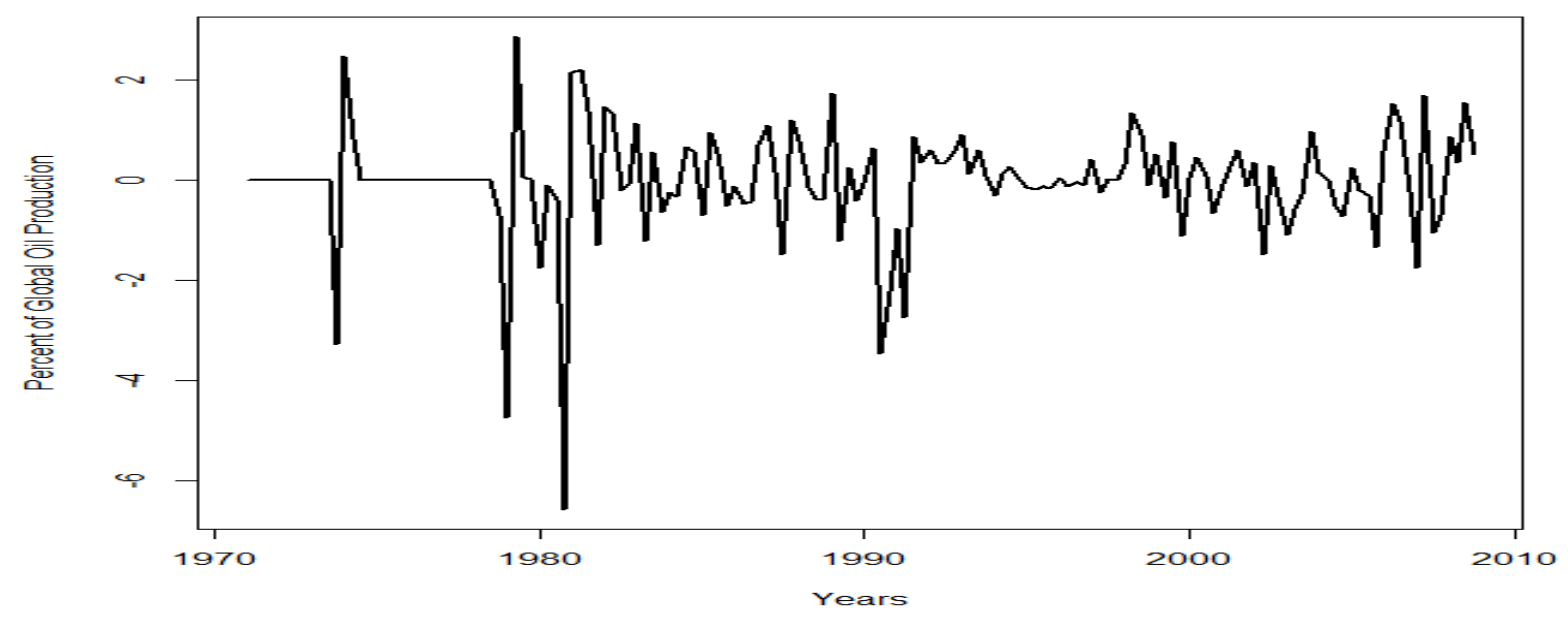

Figure 1: Exogenous Macroeconomic Shocks

Several approaches and identifying restrictions have been proposed to deal with these issues. Carlino and DeFina (1998, 1999a) attempt to avoid the aforementioned problems by estimating state-level VARs that include the state's BEA region less the state's real income, and the growth rates of real personal incomes of the other major BEA regions. Owyang and Wall (2009) split the BEA regions into 19 sub-regions. They argue that "these 19 sub-regions provide enough cross-sectional variation to discern the roles of different monetary channels, while allowing estimation in a single, tractable system” (page 1191). Barth and Ramey (2002), Fratantoni and Schuh (2003), Irvine and Schuh (2005), and Beckworth (2010) propose an 
alternative approach whereby restrictions are placed on the VAR such that each state's economy is assumed to respond to, but not to affect contiguous states.

The analysis in this paper avoids the complexities in these studies by using a single-equation linear regression model that relates real personal income to exogenous oil supply and monetary policy shocks. Because our goal is to examine how state economies respond in the wake of exogenous macroeconomic shocks, there is no need to make additional assumptions. Therefore our baseline regression consists of four lags of real personal income growth, four lags of the exogenous monetary policy shock measure and four lags of the exogenous oil supply shock measure.(Note 3) Following convention, we assume that neither monetary policy nor oil price shocks affect the economy contemporaneously.

Table 3: Augmented Dickey-Fuller (ADF) Tests for Unit Roots in State-Level Real Personal Income and Growth

\begin{tabular}{llllllll}
\hline State & Level & State & Level & State & Growth & State & Growth \\
\hline AL & -0.951 & NE & -1.037 & AL & $\mathbf{- 6 . 7 5 7}$ & NE & $\mathbf{- 7 . 4 2 4}$ \\
AZ & -0.960 & NV & -1.667 & AZ & $\mathbf{- 4 . 6 2 2}$ & NV & $\mathbf{- 5 . 4 7 9}$ \\
AR & -0.163 & NH & -2.045 & AR & $\mathbf{- 6 . 2 2 3}$ & NH & $\mathbf{- 6 . 3 0 7}$ \\
CA & -1.617 & NJ & -1.541 & CA & $\mathbf{- 5 . 1 4 7}$ & NJ & $\mathbf{- 6 . 4 4 3}$ \\
CO & -0.885 & NM & 0.286 & CO & $\mathbf{- 5 . 7 6 4}$ & NM & $\mathbf{- 7 . 1 1 4}$ \\
CT & -1.990 & NY & -1.116 & CT & $\mathbf{- 5 . 7 6 5}$ & NY & $\mathbf{- 7 . 3 4 1}$ \\
DE & -1.009 & NC & -1.289 & DE & $\mathbf{- 7 . 1 1 3}$ & NC & $\mathbf{- 6 . 4 4 4}$ \\
FL & -1.664 & ND & -2.284 & FL & $\mathbf{- 5 . 0 1 6}$ & ND & $\mathbf{- 8 . 4 2 3}$ \\
GA & -1.676 & OH & -2.096 & GA & $\mathbf{- 5 . 5 1 3}$ & OH & $\mathbf{- 6 . 1 7 4}$ \\
ID & -0.507 & OK & -0.370 & ID & $\mathbf{- 7 . 3 1 0}$ & OK & $\mathbf{- 8 . 1 6 9}$ \\
IL & -1.251 & OR & -1.124 & IL & $\mathbf{- 5 . 9 0 1}$ & OR & $\mathbf{- 5 . 5 0 2}$ \\
IN & -1.667 & PA & -1.023 & IN & $\mathbf{- 7 . 1 9 0}$ & PA & $\mathbf{- 6 . 6 3 9}$ \\
IA & -1.351 & RI & -1.317 & IA & $\mathbf{- 7 . 9 0 5}$ & RI & $\mathbf{- 6 . 5 6 9}$ \\
KS & -0.661 & SC & -1.143 & KS & $\mathbf{- 8 . 7 3 3}$ & SC & $\mathbf{- 6 . 5 3 3}$ \\
KY & -1.216 & SD & -1.275 & KY & $\mathbf{- 6 . 7 1 8}$ & SD & $\mathbf{- 8 . 9 5 6}$ \\
LA & -0.053 & TN & -1.251 & LA & $\mathbf{- 6 . 6 5 4}$ & TN & $\mathbf{- 6 . 0 4 9}$ \\
ME & -1.732 & TX & -0.408 & ME & $\mathbf{- 7 . 1 8 5}$ & TX & $\mathbf{- 5 . 6 3 9}$ \\
MD & -0.590 & UT & -0.261 & MD & $\mathbf{- 5 . 9 1 1}$ & UT & $\mathbf{- 5 . 8 7 5}$ \\
MA & -1.503 & VT & -1.255 & MA & $\mathbf{- 5 . 2 6 6}$ & VT & $\mathbf{- 7 . 1 1 4}$ \\
MI & -1.800 & VA & -0.300 & MI & $\mathbf{- 6 . 0 1 9}$ & VA & $\mathbf{- 7 . 0 0 6}$ \\
MN & -1.253 & WA & -0.539 & MN & $\mathbf{- 6 . 9 6 5}$ & WA & $\mathbf{- 9 . 0 3 7}$ \\
MS & -0.982 & WV & -1.007 & MS & $\mathbf{- 7 . 6 9 2}$ & WV & $\mathbf{- 1 0 . 4 0 1}$ \\
MO & -0.077 & WI & -0.955 & MO & $\mathbf{- 7 . 2 7 6}$ & WI & $\mathbf{- 6 . 7 3 0}$ \\
MT & -0.160 & WY & -0.418 & MT & $\mathbf{- 9 . 8 0 4}$ & WY & $\mathbf{- 5 . 1 4 7}$ \\
\hline
\end{tabular}

Notes: Equations include an intercept and time trend. Boldfaced numbers indicate significance at the $5 \%$ level. The critical value at the $5 \%$ level is -3.343

The estimation equation is therefore: 


$$
\Delta y_{t}=\alpha_{0}+\sum_{i=1}^{4} b_{i} \Delta y_{t-i}+\sum_{i=1}^{4} c_{i} \varepsilon_{m t-i}+\sum_{i=1}^{4} d_{i} \varepsilon_{o t-i}+e_{t}
$$

where $\Delta y_{t}$ is the percentage change in real personal income at time $t, \varepsilon_{m t}$ is the measure of exogenous monetary policy shocks, and $\varepsilon_{o t}$ is the series of exogenous oil supply shocks. The monetary policy shock, $\varepsilon_{m t}$, which represents unanticipated exogenous movements to the federal funds rate, and the oil supply shock, $\varepsilon_{o t}$ which represents things such as oil supply disruptions caused by external political events, are both expected to have negative effects on real personal income. Lagged income growth is included to control for the normal dynamics of income (Romer and Romer, 2010).

This direct single-equation framework has several advantages over conventional structural VAR approaches. Firstly, the fact that this approach is free of the structural identification restrictions imposed on traditional structural VAR models makes our result invariant to different identification schemes (Kilian, 2008a). Once shocks have been identified, the dynamic response of real personal incomes can be computed in a straightforward way. As pointed out by Romer and Romer (2004), the estimated response of (the level of) real personal income of state $i$ to a realization in the monetary policy shock after one quarter is just $c_{1}$; the response of real personal income of state $i$ after two quarters is $c_{1}+\left(c_{2}+\right.$ $b_{1} c_{1}$ ); and so on. Similarly, the response of real personal income of state $i$ to a realization in the exogenous oil supply shock after one quarter is just $d_{1}$; after two quarters is $d_{1}+\left(d_{2}+\right.$ $b_{1} d_{1}$ ) , and so on. Secondly, the parsimony of the model decreases the degrees of freedom problems that plague several VAR studies, thus providing a more efficient method for estimating the effects of exogenous shocks on state economies.

Of course, our empirical approach is not without limitation. One potential limitation is that the equation (1) over-assumes the lack of interstate spillovers which could bias the results. However, this limitation is not significant for the purposes of this paper for two reasons. Firstly, the shocks, $\varepsilon_{m t}$ and $\varepsilon_{o t}$ are exogenous - $\varepsilon_{m t}$ has been shown to be "relatively free of both endogenous and anticipatory actions" (Romer and Romer, 2004), while $\varepsilon_{o t}$ are oil supply shocks caused by external factors such as political instability and wars in the Middle East and other countries, which are exogenous with respect to U.S. macroeconomic conditions. Consequently, there is no need to worry about "feedback from current or lagged values of the dependent variable to the exogenous variable" (Kilian, 2008a) or spillover effects from one state to another. Secondly, the shocks in equation (1) are already identified structural shocks. The shocks are not correlated with any of the other regressors so there is no need to control for cross-state spillovers. The goal of the paper to use the identified exogenous shocks to see how they change forecasts of state income growth.

The second potential limitation is that we assume that monetary expansions and contractions, and oil supply increases and decreases have symmetric effects on state economies. Several studies, including Weise (1999), Ravn and Sola (2004), have found that the response of output (and hence income) is asymmetric in monetary expansions and contractions. Rothman (1991), and Skalin and Terrasvirta (2002) have documented asymmetries in U.S. 
unemployment rates, while Rahman and Serletis (2010) find that oil price shocks have asymmetric effects on macroeconomic variables. We acknowledge that the results in this paper are subject to the assumption that monetary expansions and contractions, and oil supply increases and decreases have symmetric effects on state economies.

\section{Results: How and Why Do States Respond Differently to Exogenous Monetary Policy and Oil Supply Shocks?}

\subsection{Aggregate Personal Income}

The results from estimating equation (1) for aggregate personal income are (t -statistics in parentheses):

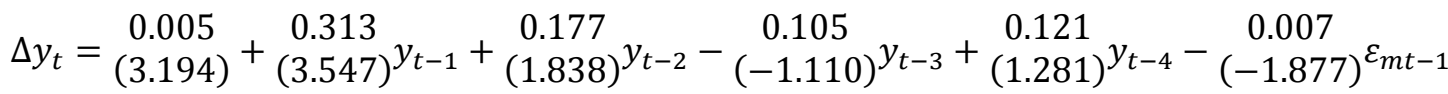

$$
\begin{aligned}
& -\underset{(-1.877)}{0.007} \varepsilon_{m t-1}-\begin{array}{c}
0.004 \\
(-1.006)
\end{array} \varepsilon_{m t-2}+\stackrel{0.002}{(0.625)} \varepsilon_{m t-3}-\begin{array}{c}
0.005 \\
(-1.255)
\end{array} \varepsilon_{m t-4}
\end{aligned}
$$

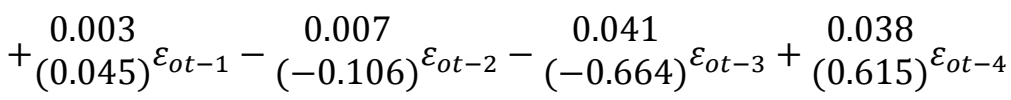

Three of the four coefficients on the monetary shock are negative, and the first is statistically significant at the 10 percent level. As the number lags increases, the significance tends to decrease. This finding of a negative response of income growth is similar to the results found in previous studies that examine the effect of monetary policy on output growth (see e.g. Christiano, Eichembaum and Evans, 1999; Occhino, 2004; Uhlig, 2005). Using monthly industrial production data, Romer and Romer (2004) also document similar results for the effects of contractionary monetary policy shocks.

Figure 2 displays the cumulative impulse response functions of aggregate real personal income to a one-percentage point realization of the monetary policy shock. The impulse response functions shown in this paper are the cumulative impulse response functions, and therefore they are interpreted as the effect of the shocks on the levels and not the growth rate of income. The above finding, that an unanticipated one-standard deviation realization in the monetary policy shock decreases real income growth temporarily, implies that the level of real personal income will be below what it otherwise would have been. This is shown in Figure 2a. The effect of the shock on real personal income, however, is not statistically different from zero. The cumulative effect of the oil supply shock is decrease in real income (although statistically different from zero, as well). This finding is similar to Kilian (2008) who finds that unanticipated global oil supply shortfalls lead to persistent decreases in the level of U.S. real GDP.

\subsection{State-Level Real Personal Income}

Figure 3 displays the impulse responses of the level of real personal income to a one percentage point realization in the monetary shock, together with their corresponding 95 percent confidence bands (the dashed lines). For comparison, we include the aggregate 
response (the gray line). Qualitatively, many states respond similar to the aggregate economy following the monetary policy shock. Quantitatively, the impulse responses show considerable variation across states. The responses of eighteen states - Alabama, Arizona, Arkansas, California, Florida, Idaho, Indiana, Maine, Michigan, Mississippi, Montana, Ohio,

(a) Response to Monetary Policy Shock

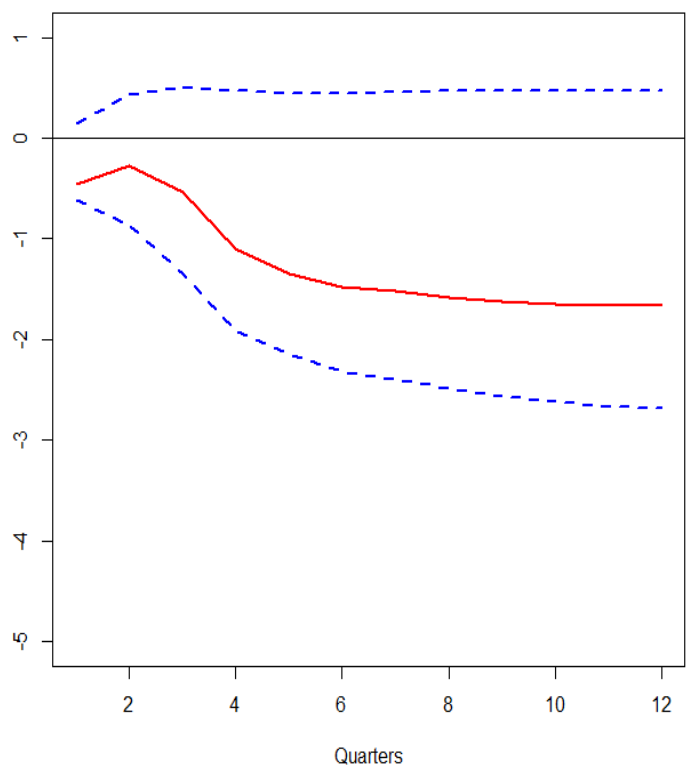

(b) Response to Oil Supply Shock

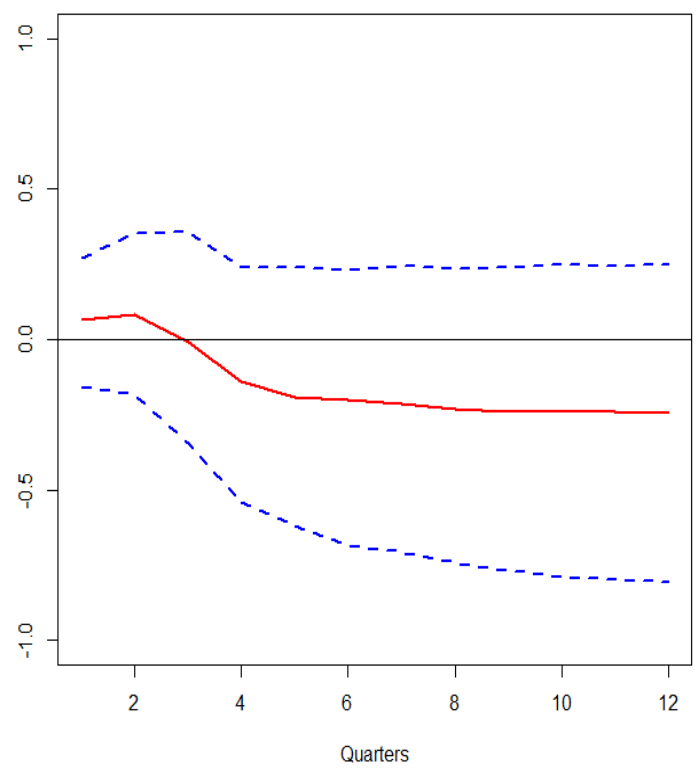

Figure 2: The Effect of Exogenous Monetary Policy and Oil Supply Shocks on Aggregate U.S. Real Personal Income

Nevada, New Hampshire, Oregon, Tennessee, Virginia, and Wyoming - are noticeably larger than the aggregate response. Carlino and DeFina (1998) identify "noncore” regions - Great Lakes, Southwest, Rocky Mountains, and the Plains - where "personal income is more responsive to monetary policy shocks than the U.S. average.” Our results indicate that even within this "non-core" region, there is considerable variation in state responses. We also find states in other regions that respond considerably larger than the aggregate response, yet are not "non-core" states. Similar to Carlino and DeFina (1999a), Figure 3 shows that Michigan has the largest response to monetary policy shocks. Of the other states, Colorado, Connecticut, Georgia, Kentucky, Maryland, Minnesota, Montana, New Jersey, Pennsylvania, Rhode Island, South Dakota, Utah, Washington, West Virginia, and Wisconsin, generally respond to exogenous monetary policy shocks similar to aggregate U.S., while five states (Illinois, Kansas, Massachusetts, New York, Texas) are least sensitive to monetary policy shocks.

What explains these differential state responses? As noted in section 2, Carlino and DeFina (1999a), and Owyang and Wall (2009) note that state differences in the mix of industries, the number of large versus small firms, and the number of large versus small banks in a state all determine the state's response to monetary shocks. In fact, Carlino and DeFina (1999a), and Owyang and Wall (2009) point out that states with a relatively large share of total state output accounted for by output in interest-sensitive industries, such as manufacturing and construction, respond more negatively to contractionary monetary shocks, while those with 
relatively large shares of state output derived from extractive industries tend to be less susceptible to contractionary monetary shocks. Figure 3 shows some evidence of this, given the significantly large responses of states such as Michigan, Indiana, Ohio, Oregon, and Wisconsin: states in which the share of gross state output accounted for by manufacturing output is relatively high (see Table 1a). As noted in section 2, states in which the share of total loans made by the state's small banks and/or share of total state employment accounted for by the state's small firms is relatively large tend to respond more significantly to monetary policy shocks than their counterparts in which the share of total loans made by the state's small banks and/or share of total state employment accounted for by the state's small firms is relatively small. Figure 3 shows that Arizona, California, Florida, Idaho, New Hampshire, Mississippi, and Vermont have relatively large responses, which are states with relatively large shares of total loans made by the states' small banks and/or large shares of total state employment accounted for by the states' small firms. The responses of three states - Arkansas, Maine, and Nevada - are noticeably greater than the aggregate response, yet have considerably small shares of gross state output accounted for by manufacturing, small shares total loans made by the small banks or small shares of total state employment accounted for by the state's small firms, suggesting that further research is needed on why states respond differently to monetary policy shocks.

Turning to the oil supply shocks, Figure 4 displays the cumulative impulse response functions of all states up to 12 quarters following a one percentage point realization in the exogenous oil supply shocks. Many states show similar patterns in their responses to exogenous oil supply shocks. After an initial overshooting, real state personal income decreases following an exogenous shock to global oil production. Six states - Delaware, Maine, Maryland, Massachusetts, New York, and Virginia - show little response to oil shocks, while Idaho, Kentucky, Mississippi, North Dakota, Oklahoma, Washington, West Virginia, Wisconsin, and Wyoming, show considerably larger responses to exogenous oil supply shocks than the aggregate response.

Like monetary policy shocks, the extent to which states respond to exogenous oil supply shocks can be explained by the extent to which such exogenous oil production shortfalls affect industry-level output and prices. States with a relatively large composition of oil-intensive industries will typically tend to be responsive to oil shocks. As shown in Table 2a to Table 2c, five of the eleven states that react relatively greater than the aggregate economy (Mississippi, North Dakota, Oklahoma, West Virginia, and Wyoming) are among the major oil producing states in the country. Therefore such large negative responses to oil supply shocks are rather surprising. However, even though oil production is a significant contributor to the gross state product, it is still substantially lower than other sectors of these states' economies. For example, in Wyoming, despite the fact that oil and natural gas extraction consist of about 17.71 percent of gross state product, other oil-sensitive industries consist of approximately 35.5 percent of gross state output (13.7 percent mining and other support services for mining (except oil and gas), 6.1 percent manufacturing, 5.8 percent transportation, and 5.6 percent construction).(Note 4) Consequently, even if oil supply shocks raise personal income through the oil and gas industries, these gains are outweighed by the 


\section{Macrothink}

Research in Applied Economics

ISSN 1948-5433

2013, Vol. 5, No. 3

loss of personal income through other oil-intensive industries, hence the reason why even major oil producing states still see decreases in personal incomes following exogenous oil supply shocks. Similar results have been documented by other researchers, including Engemann, Owyang and Wall (2011), who note that the role of oil in the business cycles of major oil producing states does not fit very well with the consensus view. Furthermore, despite the fact that these states are major oil producing states, oil production shortfalls caused by external political events do not benefit oil producing states as conventional oil price shocks because of the considerable time lag between the exogenous oil supply shortfalls and the increase in oil production in these states, if any.

AL

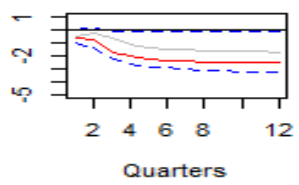

$\mathrm{CO}$

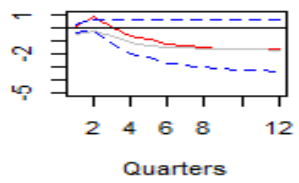

GA

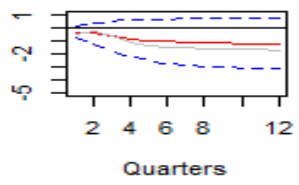

IA

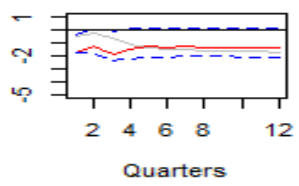

AZ

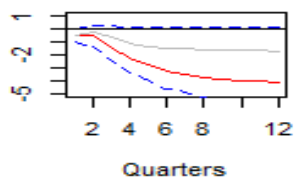

CT

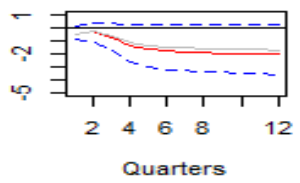

ID

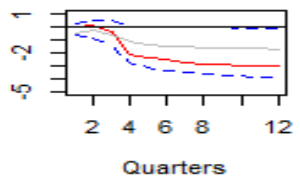

KS

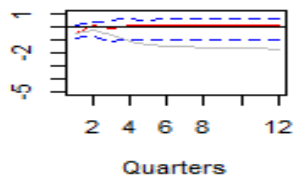

AR

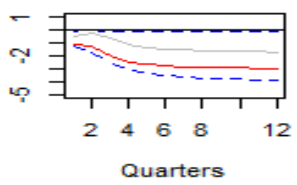

DE

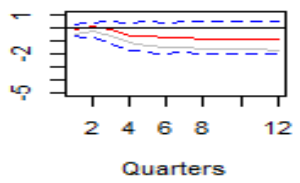

IL

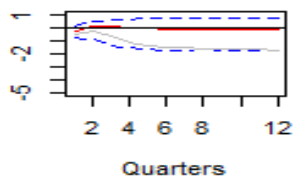

KY

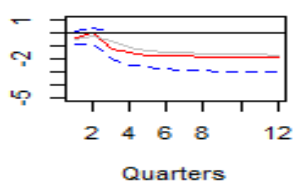

CA

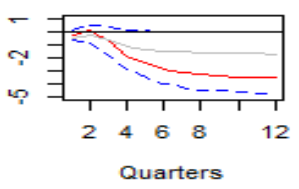

FL

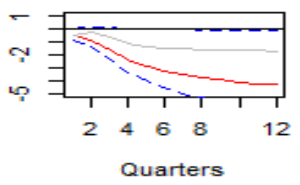

IN

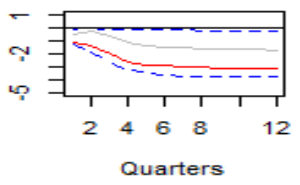

LA

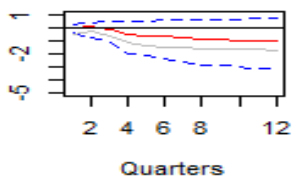




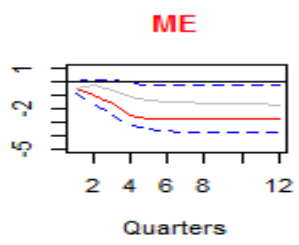

MN

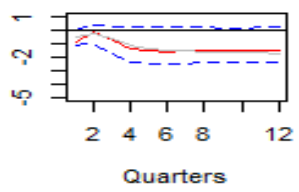

NE

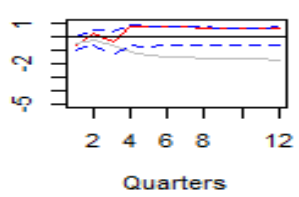

NM

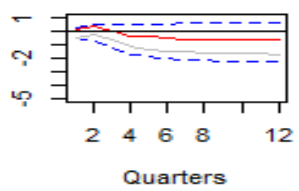

$\mathrm{OH}$

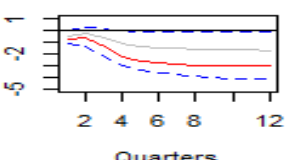

RI

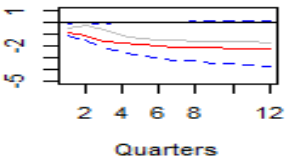

TX

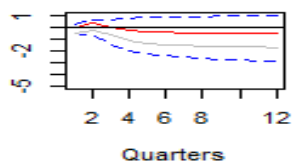

WA

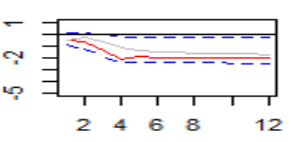

Quarters

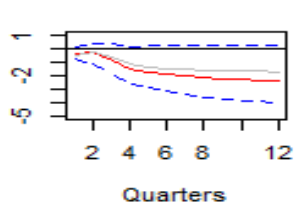

MS

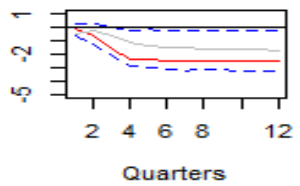

NV

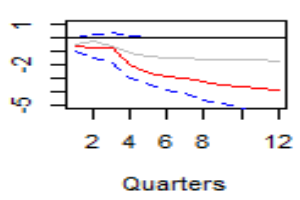

NY

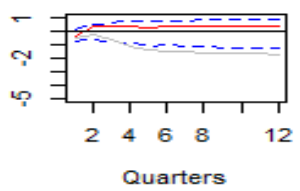

OK

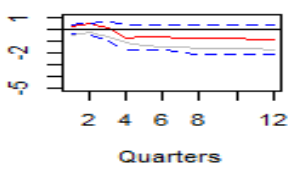

SC

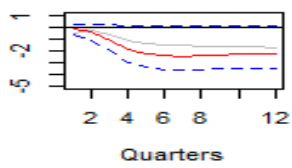

UT
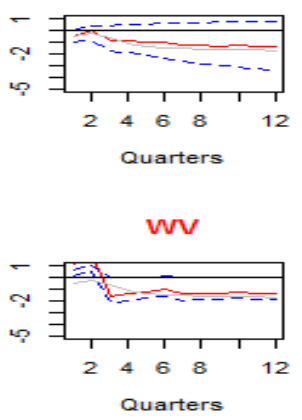

MA

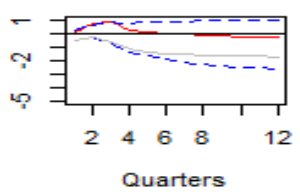

MO

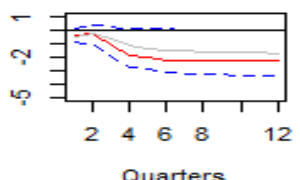

NH

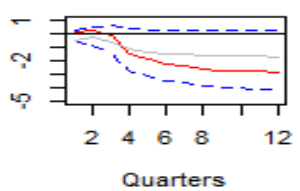

NC

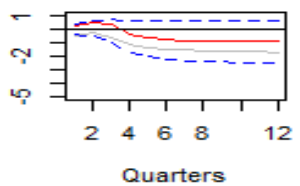

OR

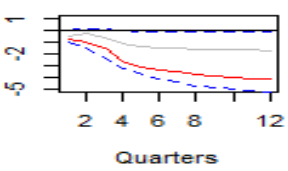

SD
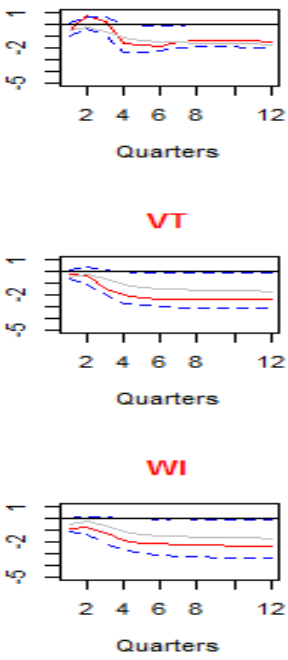

MI

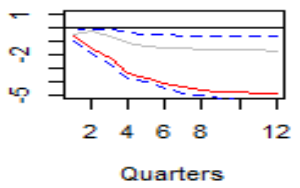

MT

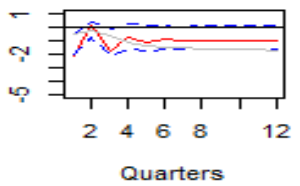

N.J

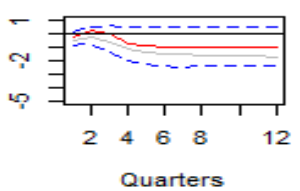

ND
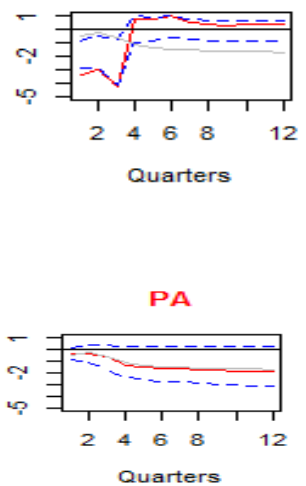

TN

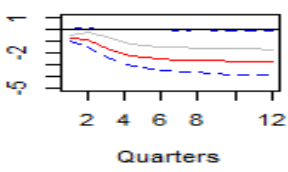

VA
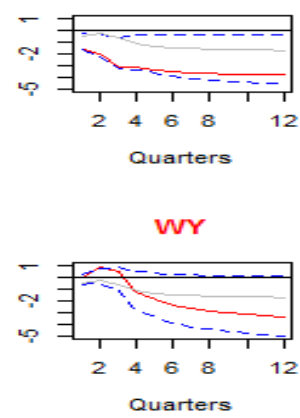

Figure 3: Response of Real Personal Income to an Exogenous Monetary Shock 


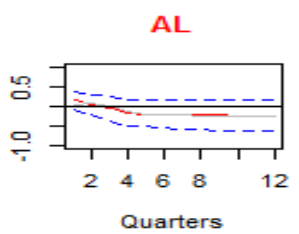

$\mathrm{CO}$

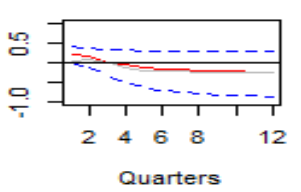

GA

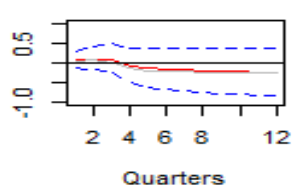

IA
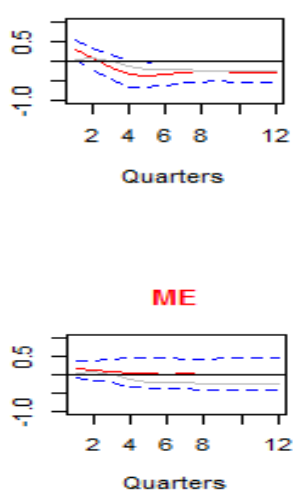

MN

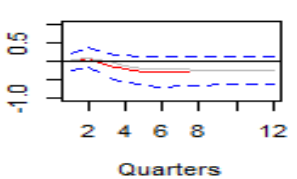

NE

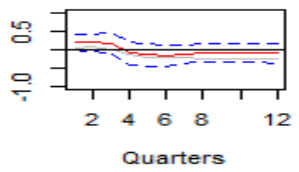

NM

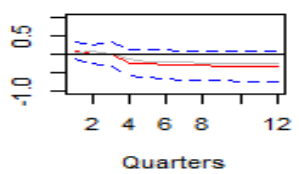

$A Z$

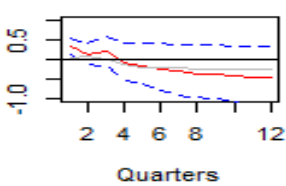

CT

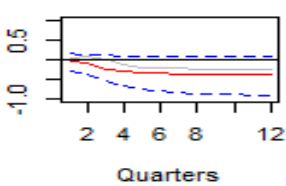

ID

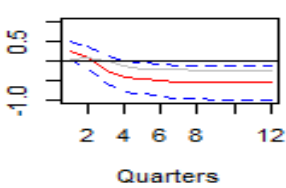

KS

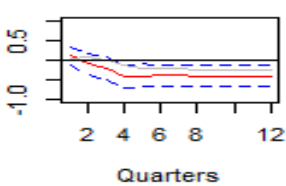

MD

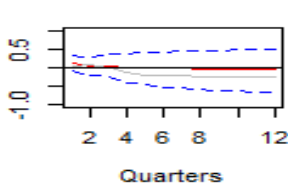

MS

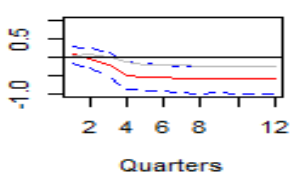

NV

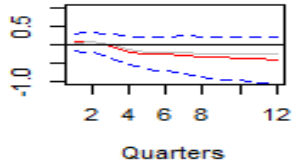

NY

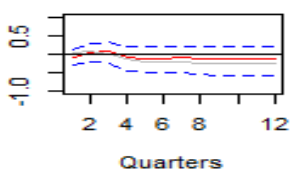

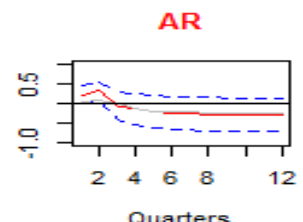

DE

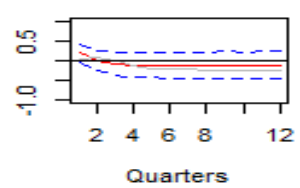

IL

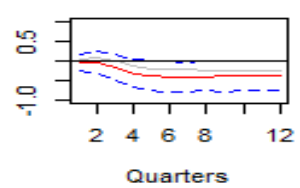

KY
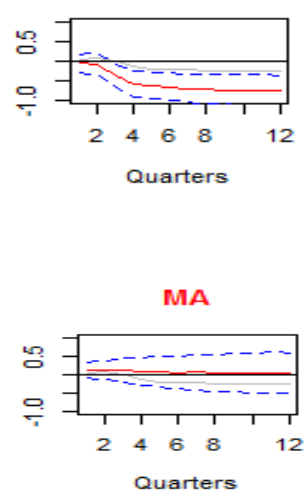

MO

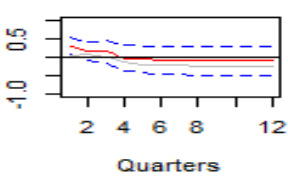

NH

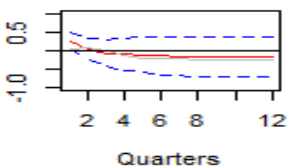

NC

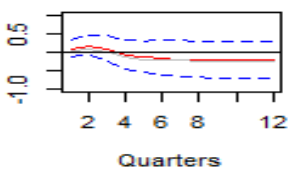

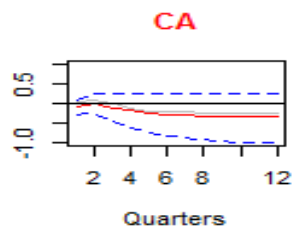

FL

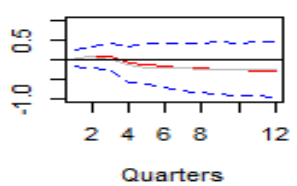

IN
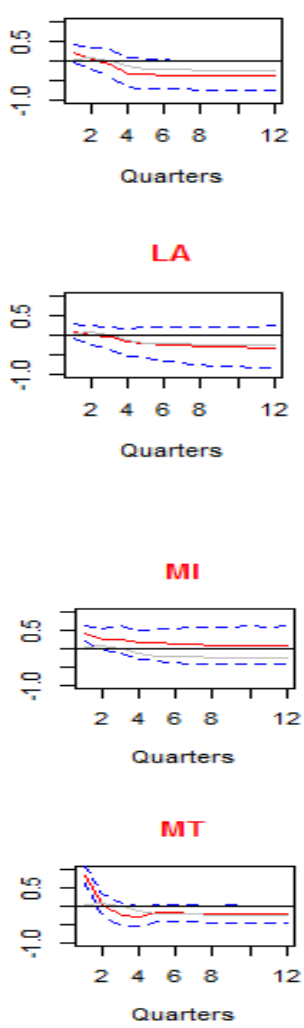

NJ

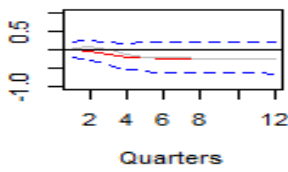

ND

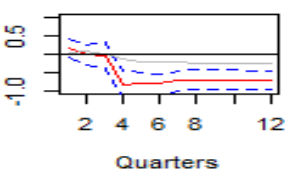




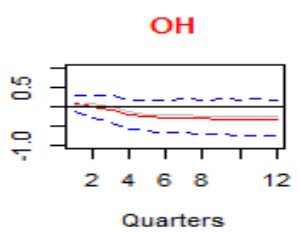

RI

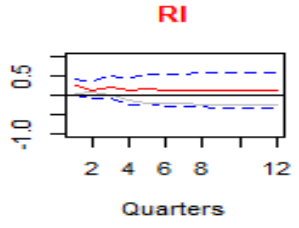

TX

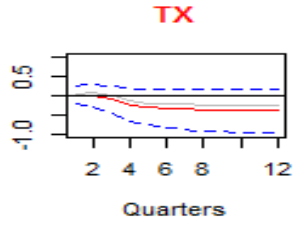

WA

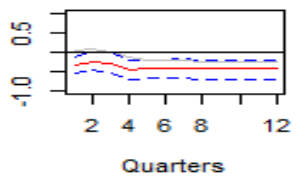

OK

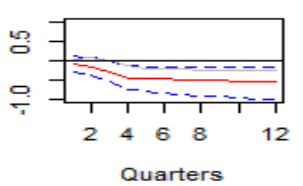

SC

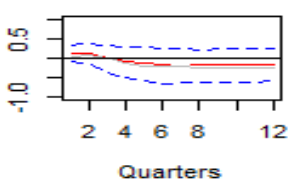

UT

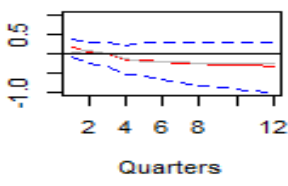

wV

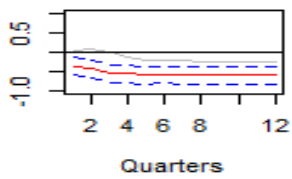

OR

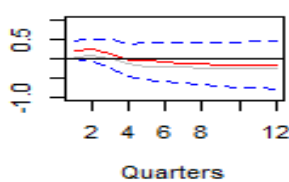

SD

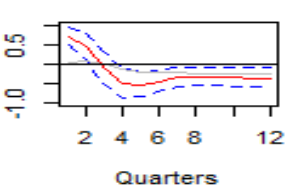

VT

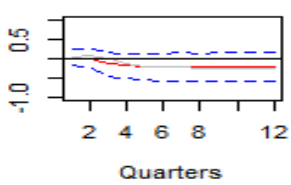

VI

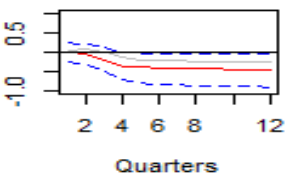

PA

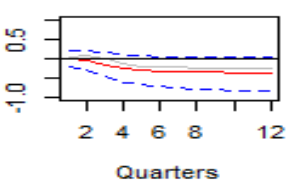

TN

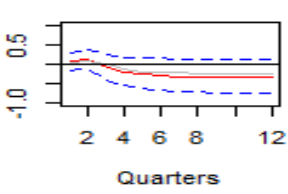

VA

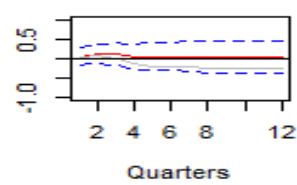

WY

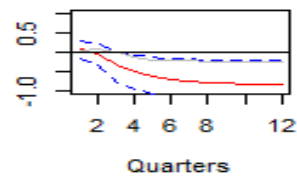

Figure 4: Response of Real Personal Income to an Exogenous Oil Supply Shock

Notes: Dark solid lines are the state impulse responses, dashed lines are the $95 \%$ confidence bands, and the gray solid lines represent the aggregate response

Not surprisingly, the six states identified above to respond least to oil supply shocks contain fewer oil-intensive industries. For example, in New York, oil and natural gas as a share of gross state product is approximately 2 percent (Table $2 b$ ), while other oil-intensive industries comprise only 11 percent (manufacturing 6 percent; construction, 3.2 percent; transportation and warehousing, 1.9 percent) of gross state product. Given the little contribution of oil in gross state product, and relatively few oil-intensive industries, the negligible response of these states to exogenous oil supply shocks is not surprising.

Figure 4 also shows that the responses of state real personal income to one percentage point realizations in the exogenous oil supply shock are considerably smaller than the corresponding responses of these states to exogenous monetary policy shocks. This result is expected because the share of oil and natural gas production, as shown in Table 2 is considerably small. In addition, Figure 1b shows that the exogenous oil supply shocks account for relatively small percent of global oil production, whereas Figure 1b shows that exogenous movements in the Federal Funds rate are considerably large.

Figures 3 and 4 show similarities and differences between many states impulse responses and the aggregate response. One implication of these results is that exogenous shocks can induce economy-wide business cycles through their effects on state-level variables. Therefore examining state-level responses of real personal income can prove invaluable to an 
understanding of the mechanism by which exogenous shocks, monetary and oil supply, affect the macroeconomy. Barth and Ramey (2002), and Lee and Ni (2002) have documented evidence of an effect of oil price shocks and monetary policy shocks on industry-level output. Carlino and DeFina (1998) point out that regional differences in the mix of interest-sensitive industries, regional disparities in the mix of large versus small firms, and regional disparities in banks' ability to alter their balance sheet all provide explanations for the differential state responses to monetary and oil supply shocks. Our results complement the findings of these studies because it builds on the premise that monetary policy shocks drive down demand for industries' products, while oil supply shocks raise cost of production, driving down supply, hence, inducing economy-wide recessions.

\section{Conclusion}

This analysis examines the relative response of U.S. state-level real personal income to exogenous oil supply shocks and monetary policy shocks, and compares these responses to the national response. Previous studies have typically employed a VAR framework to examine how state-level real personal income responds in the wake of oil supply and monetary policy shocks. Impulse responses generated using VAR models usually require making certain identifying assumptions. The results from these models therefore crucially depend on the assumptions made. In this paper, we apply a direct, single-equation approach, which avoids the conceptual and econometric difficulties employed by previous studies, to state-level economies. This approach has several advantages over conventional structural VAR approaches. Firstly, the approach is free of the structural identification restrictions imposed on traditional structural VAR models, making our results invariant to alternative identification schemes: once shocks have been identified, impulse responses can be computed in a straightforward way. Secondly, the parsimony of the model decreases the degrees of freedom problems that plague several VAR studies, thus providing a more efficient method for estimating the effects of exogenous shocks on state economies.

Qualitatively, our results indicate a good deal of similarity between the state and national responses to oil and monetary policy shocks. Following a one percentage point realization in the monetary policy shock, real state-level personal income typically declines. Quantitatively, we find considerable differences across states' real personal income responses to monetary shocks, evident is the magnitude and persistence of the effects of shocks. As hypothesized in this paper in particular, and the literature in general, state differences in the mix of industries, the number of large versus small firms, and the number of large versus small banks are potential reasons why states respond differently to monetary policy shocks. However, given that these factors do not explain completely the differential state responses to exogenous monetary policy shocks indicates that more research needs to be done on why states respond differently to exogenous monetary policy shocks. Furthermore, we find that the response of real personal income to oil supply shocks shows a pattern whereby after an initial overshooting, real state personal income decreases persistently in many states. States with relatively few oil-intensive industries show little or no responses to exogenous oil suplly 
shocks. Our results also show that states typically respond more to exogenous monetary policy shocks than to exogenous oil supply shocks, but this result is expected given that the monetary policy shocks are relatively larger than the exogenous oil supply shocks.

An implication of the results shown in this paper is that exogenous shocks - both monetary and oil supply - can induce economy-wide business cycles through their effects on state-level variables. Therefore examining state-level responses of real personal income can prove invaluable to an understanding of the mechanism by which exogenous shocks, monetary and oil supply, affect the macroeconomy.

\section{References}

Barsky, R. B., \&. Kilian, L. (2004). Oil and the Macroeconomy since the 1970s. The Journal of Economic Perspectives, 18(4), 115-134. http://dx.doi.org/10.1257/0895330042632708

Barth III, M. J., \& Ramey, V. A. (2002). The cost channel of monetary transmission. NBER Chapters, in: NBER Macroeconomics Annual 2001. National Bureau of Economic Research, 16, 199-256.

Beckworth, D. (2010). One nation under the fed? The asymmetric effects of US monetary policy and its implications for the United States as an optimal currency area. Journal of Macroeconomics, 32(3), 732-746. http://dx.doi.org/10.1016/j.jmacro.2009.12.001.

Bernanke, B. S., \& Blinder, A. S. (1992). The Federal Funds Rate and the Channels of Monetary Transmission. The American Economic Review, 82(4), 901-921. Retrieved from

http://www.jstor.org/sici?sici=0002-8282\%28199209\%2982\%3A4\%3C901\%3ATFFRA T\%3E2.0.CO\%3B2-1\&

Bernanke, B. S., Gertler, M., \& Watson, M. (1997). Systematic monetary policy and the effects of oil price shocks. Brookings Papers on Economic Activity, 1997(1), 91-157. http://dx.doi.org/10.2307/2534702

Blanchard, O. J., \& J. Galí. (2007). The Macroeconomic Effects of Oil Shocks: Why are the 2000s so different from the 1970s? National Bureau of Economic Research. http://dx.doi.org/10.2139/ssrn.1008395

Bohi, D. R. (1991). On the macroeconomic effects of energy price shocks. Resources and Energy, 13(2), 145-162. http://dx.doi.org/10.1016/0165-0572(91)90012

Carlino, G., \& DeFina, R. (1998). The differential regional effects of monetary policy. Review $\begin{array}{llll}\text { of } \quad \text { Economics } & \text { 5nd }\end{array}$ http://dx.doi.org/10.1162/003465398557843

Carlino, G., \& DeFina, R. (1999a). The differential regional effects of monetary policy: Evidence from the US states. Journal of Regional Science, 39(2), 339-358. http://dx.doi.org/10.1111/1467-9787.00137 
Carlino, G., \& DeFina, R. (1999b). Do States Respond Differently To Changes in Monetary Policy? Business Review, (July/August), 17-27. Retrieved from http://EconPapers.repec.org/RePEc:fip:fedpbr:y:1999:i:jul:p:17-27

Christiano, L. J., Eichenbaum, M., \& Evans, C. (1999). Monetary policy shocks: What have we learned and to what end? In: J. B. Taylor \& M. Woodford (ed.), Handbook of Macroeconomics, edition 1, volume 1, chapter 2, pages 65-148 Elsevier.

Cover, J. (2008). Romer and Romer's New Measure of Monetary Policy Shocks and the Nature of Supply Shocks, Working paper. http://dx.doi.org/10.2139/ssrn.1168922

Davis, S. J., \& Haltiwanger, J. (2001). Sectoral job creation and destruction responses to oil price changes. Journal of Monetary Economics, 48(3), 465-512. http://dx.doi.org/10.1016/S0304-3932(01)00086-1

Engemann, K., Owyang, M., \& Wall, H. J. (2011). Where is an oil shock? Federal Reserve Board of St. Louis Working Paper No. 2011-016A. http://dx.doi.org/10.2139/ssrn.1864716

Fratantoni, M., \& Schuh, S. (2003). Monetary policy, housing, and heterogeneous regional markets. Journal of Money, Credit, and Banking, 35, 557-590. http://dx.doi.org/10.2139/ssrn.214870

Gisser, M., \& Goodwin, T. H. (1986) Crude oil and the macroeconomy: Tests of some popular notions: A Note. Journal of Money, Credit and Banking, 18(1), 95-103.

Hamilton, J. D. (1996). This is what happened to the oil price-macroeconomy relationship. $\begin{array}{llll}\text { Journal of } & \text { Monetary }\end{array}$ http://dx.doi.org/10.1016/S0304-3932(96)01281-0

Hamilton, J. D. (2003). What is an oil shock? Journal of econometrics, 113(2), 363-398. http://dx.doi.org/10.1016/S0304-4076(02)00207-5

Hanson, M. S. (2004). The “price puzzle” reconsidered. Journal of Monetary Economics, 51(7), 1385-1413. http://dx.doi.org/10.1016/j.jmoneco.2003.12.006

Hooker, M. A. (1996). What happened to the oil price-macroeconomy relationship? Journal of Monetary Economics, $\quad 38(2), \quad 195-213$. http://dx.doi.org/10.1016/S0304-3932(96)01281-0

Hooker, M. A. (2002). Are oil shocks inflationary? Asymmetric and nonlinear specifications versus changes in regime. Journal of Money, Credit and Banking, 540-561. http://dx.doi.org/10.2139/ssrn.208890

Irvine, F. O., \& Schuh, S. (2005). Inventory investment and output volatility. International $\begin{array}{llll}\text { Journal of Production } & \text { Economics, } & \text { 93, }\end{array}$ http://dx.doi.org/10.1016/j.ijpe.2004.06.007

Kilian, L. (2008a). A comparison of the effects of exogenous oil supply shocks on output and inflation in the G7 countries. Journal of the European Economic Association, 6(1), 
78-121. http://dx.doi.org/10.1162/JEEA.2008.6.1.78

Kilian, L. (2008b). Exogenous oil supply shocks: how big are they and how much do they matter for the US economy? The Review of Economics and Statistics, 90(2), 216-240. http://dx.doi.org/10.1162/rest.90.2.216

Lee, K., \& Ni, S. (2002). On the dynamic effects of oil price shocks: a study using industry level data. Journal of Monetary Economics, 49(4), 823-852. http://dx.doi.org/10.1016/S0304-3932(02)00114-9

Occhino, F. (2004). Modeling the response of money and interest rates to monetary policy shocks: a segmented markets approach. Review of Economic Dynamics, 7(1), 181-197. http://dx.doi.org/10.1016/S1094-2025(03)00047-4

Owyang, M. T., \& Wall, H. J. (2009). Regional VARs and the channels of monetary policy. Applied Economics Letters, 16(12), 1191-1194. http://dx.doi.org/10.1080/13504850701367247

Rahman, S., \& Serletis, A. (2010). The asymmetric effects of oil price and monetary policy shocks: A nonlinear VAR approach. Energy Economics, 32(6), 1460-1466. http://dx.doi.org/10.1016/j.eneco.2010.06.003

Ravn, M. O., \& Sola, M. (2004). Asymmetric effects of monetary policy in the United States. Federal Reserve Bank of St. Louis Review, 86(5), 41-60. Retrieved from http://research.stlouisfed.org/publications/review/04/09/Ravn.pdf

Romer, C. D., \& Romer, D. H. (2010). The macroeconomic effects of tax changes: estimates based on a new measure of fiscal shocks. The American Economic Review, 100, 763-801. http://dx.doi.org/10.1257/aer.100.3.763

Romer, C. D., \& Romer, D. H. (2004). A New Measure of Monetary Shocks: Derivation and Implications. The American Economic Review, 94(4), 1055-1084. http://dx.doi.org/1055-1084.10.1257/0002828042002651

Rothman, P. (1991). Further evidence on the asymmetric behavior of unemployment rates over the business cycle. Journal of Macroeconomics, 13(2), 291-298. http://dx.doi.org/10.1016/0164-0704(91)90057-2

Skalin, J., \& Terasvirta, T. (2002). Modeling asymmetries and moving equilibria in unemployment rates. Macroeconomic Dynamics, 6(2), 202-241. http://dx.doi.org/10.1017.S1365100500000213

Uhlig, H. (2005). What are the effects of monetary policy on output? Results from an agnostic identification procedure. Journal of Monetary Economics, 52(2), 381-419. http://dx.doi.org/10.1016/j.jmoneco.2004.05.007

Weise, C. L. (1999). The asymmetric effects of monetary policy: a nonlinear vector autoregression approach. Journal of Money, Credit and Banking, 31(1), 85-108. http://www.jstor.org/stable/2601141 


\section{Al Macrothink}

Research in Applied Economics

ISSN 1948-5433

2013, Vol. 5, No. 3

Yamashiro, G., \& Grobar, L. (2005). Macroeconomic Shocks and Regional Employment: The Case of Southern California. Journal of Regional Analysis and Policy, 35(2), 24-36. http://purl.umn.edu/132307

\section{Notes}

Note 1. See, for example, Gisser and Goodwin (1986), Bohi (1991), Hamilton (1996, 2003), Hooker (1996, 2002), Bernanke, Gertler and Watson (1997), Christiano, Eichenbaum and Evans (1999), Davis and Haltiwanger (2001), Barsky and Kilian (2004), Rahman and Serletis (2010).

Note 2. See e.g. Christiano, Eichenbaum and Evans (1999), Carlino and DeFina (1998, 1999a), Yamashiro and Grobar (2005), Owyang and Wall (2006), Beckworth (2010), Engemann, Owyang and Wall (2011), among others.

Note 3. Other papers that have employed a similar methodology include Hamilton (2003), Romer and Romer (2004), and Kilian (2008a).

Note 4. http://bea.gov/iTable/iTable.cfm?ReqID=70\&step=1\&isuri=1\&acrdn=1

\section{Copyright Disclaimer}

Copyright reserved by the author(s).

This article is an open-access article distributed under the terms and conditions of the Creative Commons Attribution license (http://creativecommons.org/licenses/by/3.0/). 